\title{
Dysphemism Lexical Items of Hate Speeches: Towards Education of Students for Political Correctness
}

\author{
I Nyoman Pasek Darmawan* \\ Postgraduate English Department \\ Universitas Mataram \\ Mataram Indonesia \\ inyomanpasekdarmawan@gmail.com
}

\author{
Lalu Muhaimi \\ Postgraduate English Department \\ Universitas Mataram \\ Mataram Indonesia
}

\begin{abstract}
This paper aimed at identifying and organizing any dysphemism lexical items used by people in disseminating hate speech expressions through Social Media posts and also teaching the political correctness to the students in order to avoid the use of hate speech items in their daily encounters especially in terms of using social media. This was qualitative study which described the use of nine dysphemism types of the hate speech on social media based on seven Indonesian Supreme Court's decisions. Observation, note-taking, and substitution techniques were used to collect the data from the Indonesian Supreme Court's decision by using purposive sampling technique. In order to analyze the data, the first step was organizing data, then followed by transcribing and converting the result of note-taking into text data and finally organizing them into the nine types of dysphemism. The result of the study showed that there are 32 words/phrases found in seven decisions of hate speech on Social Media contents concerning nine types of dysphemism. Most hate speeches on the Social Media contents are found in "-ist" dysphemism type within 15 words/phrases (46.875\%), then followed by synecdoche - 10 words/phrases (31.25\%), dysphemistic epithets (4 words/phrases or $12.5 \%$ ), and name dysphemism with 3 words/phrases $(9.375 \%)$. Meanwhile, there are no words or phrases which related to the rest five types of dysphemism; euphemistic dysphemism, dysphemistic euphemism, homosexual dysphemism, non-verbal dysphemism, and cross-cultural dysphemism.
\end{abstract}

Keywords - dysphemism, hate speech, social media

\section{INTRODUCTION}

Recently, hate speech is popular in Indonesia as current popular phenomena in Indonesian society. Hate speeches are any expressions which humiliate to any race, religious, ethnic, or particular national group through racism, xenophobia, interethnic hostility or intolerance, instigating violence, hatred or discrimination [1]. A concept of hate speech tends to be linked to the terms such as 'group defamation', 'incitement to hatred', the circulation of ideas based on inferiority', 'racist propaganda', 'speech xenophobia, homophobia, Islamophobia, and antiSemitism', 'group vilification', 'violation of dignity', discrimination harassment', 'racist fighting words' and 'Holocaust denial' [2]. Hate speech is a communication act which is deliberately carried out by a person or specific groups in terms of jibes, provocations, or incitements to an individual or particular community regarding some aspects such as race, gender, sexual orientation, nationality, skin tone, religion, and etc. The term of hate speech refers to purposeful communicative actions which are conducted verbally or symbolically and intended against some groups of people or an individual who are coming from different ethnicity, religion, or sexual orientation [3]. The Council of Europe, Committee of Ministers recommendation no. 97(20) states that all forms of expression which spread, incite, promote or justify racial hatred, xenophobia, antiSemitism or other forms of hatred based on intolerance through aggressive nationalism and ethnocentrism, discrimination and hostility against minorities, migrants and people of immigrant origin. Hate speech mostly expressed both directly and indirectly or disguised by terms of dysphemism words or phrases.

The term of dysphemism can be defined as an adjective which is used to express opinions or facts by way of abusive or impolite words or phrases in order to show up an offensive, disagreeable, disappointment, hatred, or anger [4]. Dysphemism words may be used to bring attention to an issue, or to demonstrate a lack of political conformity [5]. Dysphemism is regarded as the opposite of euphemisms in the way of the variance of reference of locution (words form) as well as the illocutionary point of the utterance with connotations that are offensive and they are used to substitute neutral or euphemistic expression [6]. There are currently nine recognized types of dysphemism: (1) synecdoche; used to describe something as a whole, (2) dysphemistic epithets; the use of animal names, (3) euphemistic dysphemism; using soft expression without offending, (4) dysphemistic euphemism; a mockery between close friends without any animosity, (5) "-ist" dysphemism; targeted at a particular ethnicity, (6) homosexual dysphemism; used regarding homosexuality, (7) name dysphemism; calling someone's name without proper title, (8) non-verbal dysphemism; offending someone with gestures, and (9) cross-cultural dysphemism; using different terms of slang based on particular culture to other cultures.

The rapid and dynamic progress and development of technology also contributed in terms of accessing any information especially in the field of communication medium. The term of social media which refers to the applications or websites which facilitate people nowadays to access or share any contents quickly, efficiently, and in real-time [7]. It cannot be denied that social media as reputable interactive computer-mediated technologies that have facilitated many people to get or share information, ideas, career, or interests through virtual communities on network. There are four types of the most used social media applications which are used by people nowadays, 
especially in Indonesia, such: (1) Facebook, (2) YouTube, (3) Instagram, and (4) Twitter.

The relation between hate speech expressions and social media can be seen from recent cases where many people transformed the positive benefits of social media into the negative such as hate speech contents on their social media platforms. The head of Nusantara task force (Kasatgas Nusantara), Irjen Pol Gatot Eddy Pramono conveyed that the data of hate speech dissemination through social media reached 3.884 contents from the mid of 2017 to December 2018 and the data of hoax and hate speech expressions are made by 643 real accounts, 702 semi-anonym accounts and 2.533 anonym accounts [8]. Popularly, the perpetrators of hate speech use abusive languages (i.e. dysphemism languages) in their contents

Nowadays, in Indonesia for example, hate speech contents can be found on social media such as Facebook, Twitter, Instagram and YouTube. Many irresponsible people use them to share anything regarding the expressions of hate speech which are oriented to provoke other people to speak the same language as they did or shared. Some underlying factors which cause the dissemination of hate speech expressions are political competition, social conditions, racial, ethnic or religious view differences. Two factors such as individual psychology and psychiatric conditions act as internal factor and the lack of social control of the environment as the external factor may trigger the dissemination of hate speech [9].

In Indonesia, a law which rules the dissemination of hate speech expressions via social media is formed as the Law Number 19 Year 2016 Concerning Amendment to Law Number 11 Year 2008 on Information and Electronic Transaction. Mostly, people who intend to share hate speech expressions tend to use dysphemism expressions or phrases in their social media contents in order to attack their opposites. Dysphemism is known as an adjective which is used to express opinions or facts by way of abusive or impolite words or phrases in order to show up an offensive, disagreeable, disappointment, hatred, or anger. Examples of dysphemism can be seen such as ...kagak gue takut ama kalian peler... (I'm not afraid of you $\mathrm{d}^{*} \mathrm{ck}$ ) or ...kalian penghianat... (You are traitor).

There are three previous related studies involved as the comparison of this study that equally allude to the hate speech and dysphemism expressions. The first result comes out from the study of Analisis Faktor Penyebab Pelaku Melakukan Ujaran Kebencian (Hate Speech) Dalam Media Sosial by Febriyani [10]. She concluded that there are two factors regarding hate speech dissemination on social media; internal factors including the user's psychology and psychiatric conditions, whereas external factors involving environment factor, the lack of social control of the environment, community's interests, ignorance of society, and facilities as well as technology development. Secondly, Bako on her study entitled Budaya Popular dan Komunikasi: Penggunaan Disfemia Para Netizen Pada Akun Instagram Lambe_Turah has revealed that based on the result of research, there are 33 words, 11 phrases, and 19 idioms which contain dysphemism of hate speech expressions [4]. In addition, she states that linguistic SPEAKING (Setting and Scene, Participants, Ends, Act Sequences, Key, Instrumentalities, Norms of Interactions, and Genres) elements were found in each comment on Lambe_Turah Instagram account. However, she did not mention in what type of dysphemism they are in. The third previous study comes from Mondal, Silva, and Benevenuto entitled A Measurement Study of Hate Speech in Social Media which is concerning on the analysis of hate speech on social media especially from Whisper and Twitter [1]. Overall, the result of their strategy identified that different social media are found to have different contains of hate speech [11]. They state that Twitter consists of 20,305 tweets of hate speech while Whisper consists of 7,604 whispers. By following those data, racist hate words like 'Black people' $(4.91 \%$ on Twitter, $10.10 \%$ on Whisper), 'White people' $(9.76 \%$ on Twitter, $5.62 \%$ on Whisper), or 'Nigga' (31.11\% on Twitter) are dominated. The results or data obtained from those three previous studies are used as sources, references and standards of results in order to support this study optimally.

However, the problem is that there is no specific or standard use of dysphemism utterances which can be categorized as hate speech expressions. In the other words, there are no standard lexical items cited in the constitutions that can be organized as the group of hate speech words. It is useful in order to identify and organize any dysphemism lexical items used by social media users in disseminating hate speech expressions based on the Indonesian Supreme Court Decisions and hopefully it can be references for standard lexical items of hate speech in order to maintain and teach the political correctness to the students in order to avoid the use of hate speech utterances in their daily encounters especially in terms of using social media. Departing from the explanations and issues above, this study will be conducted in order to answer the following questions:

- Is there any kind of dysphemism consisted in some hate speech posts on Social Media based on the Decisions of Indonesian Supreme Court?

- What type of dysphemism that mostly used by people in disseminating hate speech on Social Media posts?

\section{METHOD}

The idea of this study was carried out by doing observation through any contents of hate speech which may consist of dysphemism expressions. Mostly, the contents are based on seven decisions of Indonesian Supreme Court regarding some deviations of the use of hate speech on Social Media. This is an analysis study which uses qualitative methods. ${ }^{[11][12]}$ Qualitative method refers to a method of research in which the researcher focuses on exploring a problem and developing any solutions as the understanding regarding the problem of a central phenomenon. Qualitatively, this study aims to describe the use of dysphemism expressions of hate speech on social media specifically on Social Media posts based on nine types of dysphemism.

The subjects of this study are seven decisions which have been appointed as hate speech expression by means 
of Indonesian Supreme Court Decisions by using purposive sampling technique. Purposive sampling technique means that the subjects or data of this study are obtained and selected intentionally concerning the phenomenon of dysphemism of hate speech contents. Sequential exploratory strategy was used for this study which involves collecting and analyzing qualitative data.

Observation, note-taking, and substitution techniques were used to collect the data. Firstly, on the observation technique, any kind of posts on Social Media that have been appointed by the Supreme Court were observed in order to define which utterances that are categorized as dysphemism. Secondly, any hate speech posts were collected through taking note technique. Thirdly, those posts were examined in order to analyze or identify the emergence of nine types of dysphemism expressions in each post. Finally, substitution technique was used to substitute the use of informal language to formal forms in order to facilitate the researcher to categorize words or phrases into each type of nine dysphemism.

In order to analyze the data, the first step is organizing data. At this early stage, any collected posts were organized based on its sources of decisions. Second, the data were transcribed by converting the result of taking note into text data. Thus, it would be easier to categorize them into each type of nine dysphemism. Third, Microsoft Office Excel 2016 program was used in order to measure the percentage of the emergence of nine dysphemism types. Graphic data were provided to visualize the percentage of the data. Hence, due to the use of mixed method (i.e. combination of qualitative and quantitative methods), the results of this study will be displayed as descriptive qualitative and then followed by the visualization of graphic data of the emergence of dysphemism percentages.

\section{FINDINGS AND DISCUSSION}

This study focused on the analysis of the use of dysphemism utterances in any Social Media posts that are categorized as hate speech posts by the decisions of Indonesian Supreme Court. The data of finding were taken by investigating and analyzing 7 (seven) decisions of Indonesian Supreme Court regarding any animosity or hate speech posts on Social Media such as Facebook, Twitter, and YouTube.

Based on the samples used, this study was only focused on the emergences of dysphemism in those Social Media posts. The result of this study showed that based on seven samples used, the use of "-ist" dysphemism type (i.e. dysphemism that is targeted at a particular ethnicity) is ranked at the first place as dominant use of dysphemism with 15 words/phrases recognized such: (1) "para antek2 RRC dan imigran RRC??”, (2) "meski Al-Quran dibakar china kafir umat islam mampu menahan diri", (3) "kukira ito tadi muslim, sedih karena ternyata islam itu agama setan...", (4) "org dablek yang haram makan dging babi”, (5) "dalam Islam Babi haram tapi (meniduri) babu halal”, (6) "dulu cina anti pemilu”, (7) "cina cacatpun datang ke TPS", (8) "mayoritas, cina itu memang babi", (9) "makan tu Islam kalian gak punya otak", (10) "ketauan sekali busukx ajaran kalian”, (11) “\#pki para pembenci islam berbaju kotak kotak”, (12) “laurens kevin paliama kristen teroris berkalung salib membawa parang gemar membacok orang", (13) "budak2 antek rrc", (14) "hebo x yg nonton G30 s pki eehh kya nh semua orang bau bau nh pki semua" and (15) "orang baubau semua PKI".

Secondly, the most used dysphemism in the Social Media contents is found at synecdoche type or dysphemism to describe something or somebody as a whole, 10 words/phrases, within details: (1) "kukira ito tadi muslim, sedih karena ternyata Islam itu agama setan...", (2) "mereka adalah boneka-boneka yang terjebak dalam Mugen Tsukoyomi...", (3) "penguasa negara tsb beserta rakyatnya kafir kabeh", (4) "di dor mau sama densus kek emang gue pikirin peler peler hidup...", (5) "kagak gue takut ama kalian peler gue takut ama kalian kontol siapa kalian, kalian penghianat, kalian penghianat bangsa ini", (6) "Ahok 'si Penista Agama",, (7) "Rezim ini memamerkan kekuasaan dengan cara kampungan, norak, sekaligus (maaf) menjijikan”, (8) "Penista agama adalah bajingan yang perlu diludahi mukanya", (9) "pada goblok semua" and (10) "\#fakta. Said Agil itu kyai penipu dan doyan uang...”.

In the term of insulting people by using animals name or dysphemistic epithets, the use of animal names such as donkey (keledai), pig (babi), or camel (unta) are found as in these four phrases: (1) "mereka itu seperti keledai liar pak...", (2) “emang susah Her bicara ama kaum yang bebal \& lebih bodoh dari onta...", (3) "mayoritas, cina itu memang babi”, and (4) "... agar orang-orang yang sebabkan si babi dipenjara harus dipenjara juga”.

At the fourth rank or the last rank is filled up by the use of name dysphemism type (i.e. the use of dysphemism when someone is called by his name, rather than by using his/her proper title) which consists of three phrases as follows: (1) "bahwasanya jokowi telah berpihak pada blok komunis jokowi", (2) "jokowi memerintahkan anteknya yang bernama Tito Karnavian", and (3) "sejak ada JKWAhok".

The amount of the emergence of nine dysphemism types can be displayed in the Table 1 below:

TABLE I. THE AMOUNT OF NINE DYSPHEMISM EMERGENCE

\begin{tabular}{|l|c|}
\hline \multicolumn{1}{|c|}{ Type } & Emergence \\
\hline Synecdoche & 10 \\
\hline Dysphemistic epithets & 4 \\
\hline Euphemistic dysphemism & 0 \\
\hline Dysphemistic euphemism & 0 \\
\hline "-Ist" dysphemism & 15 \\
\hline Homosexual dysphemism & 0 \\
\hline Name dysphemism & 3 \\
\hline Non-verbal dysphemism & 0 \\
\hline Cross-cultural dysphemism & 0 \\
\hline Total & 32 \\
\hline
\end{tabular}

Typically, most Social Media posts are referred to insult people who are coming from different social culture or religion by stating the names of different ethnics or communities directly in the posts. By using Microsoft Office Excel 2016, the percentages of nine types of dysphemism are illustrated as the following graph. 


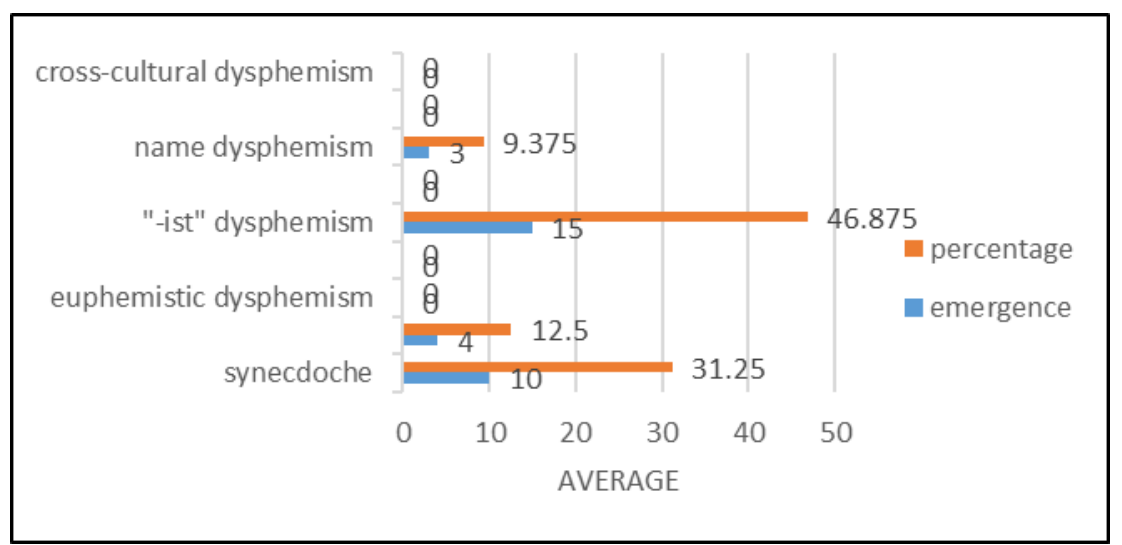

Fig. 1. The Percentages of Nine Types of Dysphemism

\section{CONCLUSION}

Based on the data explained in the previous part, it can be concluded that there are several use of dysphemism types in each content of Social Media which has been avowed by the Indonesian Supreme Court as hate speech contents. Regarding seven samples of Supreme Court decisions, there are 32 words or phrases found related to the use of dysphemism in the Social Media contents.

Concerning nine types of dysphemism, most hate speeches on the Social Media contents are found in "-ist" dysphemism type within 15 words/phrases (46.875\%), then followed by synecdoche - 10 words/phrases (31.25\%), dysphemistic epithets (4 words/phrases or $12.5 \%$ ), and name dysphemism with 3 words/phrases $(9.375 \%)$. Meanwhile, there are no words or phrases which related to the rest five types of dysphemism; euphemistic dysphemism, dysphemistic euphemism, homosexual dysphemism, non-verbal dysphemism, and cross-cultural dysphemism.

\section{REFERENCES}

11 L. Silva, M. Mondal, D. Correa, F. Benevenuto, and I. Weber, "Analyzing the targets of hate in online social media," in Tenth International AAAI Conference on Web and Social Media, 2016.

[2] A. Brown, "What is hate speech? Part 1: The myth of hate," Law Philos., vol. 36, no. 4, pp. 419-468, 2017.

[3] M. Rosenfeld, "Hate speech in constitutional jurisprudence: a comparative analysis," Cardozo L. Rev., vol. 24, p. 1523, 2002.

[4] E. N. Bako, "BUDAYA POPULAR DAN KOMUNIKASI: BENTUK DISFEMIA PARA NETIZEN PADA AKUN INSTAGRAM LAMBE_TURAH," Bhs. Indones. Prima, vol. 1 , no. 2, pp. 56-61, 2019.

[5] K. Allan and K. Burridge, "Censoring of Language. New York: Cambridge University Press. Paper-back ISBN 0-52152564-0; Hardback ISBN 0-521-81960-1; 303pp. Price: $\mathfrak{f}$ 17.99. Reviewed by Kevin Harvey, School of English Studies, University of." 2008.

[6] K. Burridge, "Euphemism and language change: The sixth and seventh ages," Lexis. J. English Lexicology, no. 7, 2012.

[7] M. Hudson, "What Is Social Media?," 2019. https://www.thebalancesmb.com/what-is-social-media2890301 (accessed Jun. 28, 2019).

[8] Sarah Hutagaol, "Berapa Jumlah Hoaks \& Ujaran Kebencian dari 2017-2018? Berikut Datanya," 2019. https://nasional.okezone.com/read/2019/01/15/337/2004711/be rapa-jumlah-hoaks-ujaran-kebencian-dari-2017-2018-berikutdatanya (accessed Jun. 28, 2019).

[9] H. R. SAPUTRO, "ANALISIS YURIDIS UJARAN KEBENCIAN (Hate Speech) DI MEDIA SOSIAL DITINJAU DARI PRESPEKTIF HUKUM PIDANA.” UNIVERSITAS MUHAMMADIYAH PURWOKERTO, 2018.

[10] M. Febriyani, "Analisis faktor penyebab pelaku melakukan ujaran kebencian (hate speech) dalam media sosial," 2018.

[11] M. Mondal, L. A. Silva, and F. Benevenuto, "A measurement study of hate speech in social media," in Proceedings of the 28th ACM Conference on Hypertext and Social Media, 2017, pp. 85-94. 